\title{
Interrupted/bipartite clavicle as a diagnostic clue in Kabuki syndrome
}

DOI:

10.1002/ajmg.a.38131

\section{Document Version}

Accepted author manuscript

Link to publication record in Manchester Research Explorer

\section{Citation for published version (APA):}

Haanpää, M., Schlecht, H., Batra, G., Clayton-Smith, J., \& Douzgou, S. (2017). Interrupted/bipartite clavicle as a diagnostic clue in Kabuki syndrome. American Journal of Medical Genetics, Part A, 173(4), 1115-1118.

https://doi.org/10.1002/ajmg.a.38131

\section{Published in:}

American Journal of Medical Genetics, Part A

\section{Citing this paper}

Please note that where the full-text provided on Manchester Research Explorer is the Author Accepted Manuscript or Proof version this may differ from the final Published version. If citing, it is advised that you check and use the publisher's definitive version.

\section{General rights}

Copyright and moral rights for the publications made accessible in the Research Explorer are retained by the authors and/or other copyright owners and it is a condition of accessing publications that users recognise and abide by the legal requirements associated with these rights.

\section{Takedown policy}

If you believe that this document breaches copyright please refer to the University of Manchester's Takedown Procedures [http://man.ac.uk/04Y6Bo] or contact uml.scholarlycommunications@manchester.ac.uk providing relevant details, so we can investigate your claim.

\section{OPEN ACCESS}


Part A

\section{Interrupted/bipartite clavicle as a Diagnostic Clue in Kabuki Syndrome.}

\begin{tabular}{|c|c|}
\hline Journal: & American Journal of Medical Genetics: Part A \\
\hline Manuscript ID & 16-0645.R2 \\
\hline Wiley - Manuscript type: & Clinical Report \\
\hline Date Submitted by the Author: & $\mathrm{n} / \mathrm{a}$ \\
\hline Complete List of Authors: & $\begin{array}{l}\text { Haanpää, Maria; Central Manchester University Hospitals NHS Foundation } \\
\text { Trust, Manchester Centre for Genomic Medicine; TYKS, Department of } \\
\text { Clinical Genetics } \\
\text { Schlecht, Helena; Central Manchester University Hospitals NHS Foundation } \\
\text { Trust, Manchester Centre for Genomic Medicine } \\
\text { Batra, Gauri; Central Manchester University Hospitals NHS Foundation } \\
\text { Trust, Department of Perinatal Histopathology } \\
\text { Clayton-Smith, Jill; St Mary's Hospital, Medical Genetics Research Group } \\
\text { and Regional Genetics Service; University of Manchester Faculty of Medical } \\
\text { and Human Sciences, Institute of Evolution, System and Genomics } \\
\text { Douzgou, Sofia; Central Manchester University Hospitals NHS Foundation } \\
\text { Trust, Manchester Centre for Genomic Medicine; University of Manchester } \\
\text { Faculty of Medical and Human Sciences, Institute of Evolution, System and } \\
\text { Genomics }\end{array}$ \\
\hline Keywords: & bipartite clavicle, Interrupted clavicle, Kabuki syndrome, KMT2D \\
\hline Search Terms: & \\
\hline
\end{tabular}


Interrupted/bipartite Clavicle as a Diagnostic Clue in Kabuki Syndrome.

\author{
M. Haanpää ${ }^{1,2}$, H. Schlecht ${ }^{1}$, G Batra $^{3}$, J. Clayton-Smith ${ }^{1,4}$, S. Douzgou ${ }^{1,4^{*}}$. \\ ${ }^{1}$ Manchester Centre for Genomic Medicine, Central Manchester University hospitals \\ NHS Foundation trust, UK Manchester Academic Health Sciences Centre, \\ Manchester M13 9WL, Manchester M13 9WL, United Kingdom. \\ ${ }^{2}$ Turku University Hospital, Finland. \\ ${ }^{3}$ Department of Perinatal Histopathology, Central Manchester University Hospitals \\ NHS Foundation Trust, Manchester M13 9WL, United Kingdom. \\ ${ }^{4}$ Institute of Evolution, Systems and Genomics, Faculty of Medical \& Human \\ Sciences, University of Manchester, United Kingdom. \\ *corresponding author \\ Email: sofia.douzgou@cmft.nhs.uk
}

John Wiley \& Sons, Inc. 


\begin{abstract}
Kabuki syndrome is a rare developmental disorder characterized by typical facial features, postnatal growth deficiency, mild to moderate intellectual disability and minor skeletal anomalies. It is caused by mutations of the KMT2D and KDM6A genes while recently $R A P 1 A$ and $R A P 1 B$ mutations have been shown to rarely contribute to the pathogenesis. We report two patients' presentation of Kabuki syndrome caused by different $K M T 2 D$ mutations, both including an interrupted/bipartite clavicle. The clinical diagnosis of Kabuki syndrome may be challenging, especially in younger patients and we suggest that the observation of a bipartite clavicle may be an additional diagnostic clue to prompt investigation for Kabuki syndrome. We also hypothesize that bipartite/pseudofractured clavicles or other skeletal defects may be under-recognized features of the clinical presentation of the chromatin remodeling disorders.
\end{abstract}

Keywords: Interrupted clavicle, bipartite clavicle, Kabuki Syndrome, KMT2D 


\title{
Introduction
}

\author{
Kabuki syndrome (KS; OMIM 147902), first described by Niikawa et al. \\ [1981] and Kuroki et al. [1981], is characterized by distinctive craniofacial features \\ highlyarched and interrupted eyebrows, elongated palpebral fissures with an eversion \\ of the lateral third of the lower eyelid, a broad and depressed nasal tip with a short \\ columella, downturned mouth with a full lower and a thin upper lip, large and \\ prominent ears, mild to moderate intellectual disability, postnatal growth deficiency, \\ persistence of fetal fingertip pads, minor skeletal abnormalities and various internal \\ organ malformations [Bogershausen and Wollnik, 2013]. \\ Kabuki syndrome is a heterogeneous condition and pathogenic mutations in \\ KMT2D and KDM6A have been identified by numerous studies. Both KMT2D and \\ KDM6A, two major components of the ASCOM methyltransferase complex, are \\ important for chromatin state and transcriptional activation [Goo et al., 2003]. \\ Recently, it has been suggested that the KS pathophysiology overlaps with that of the \\ RASopathies, on the basis of the aberrations or dysfunction of the MAPK pathway in \\ both. Mutations in the genes $R A P 1 A$ and $R A P 1 B$ cause similar craniofacial \\ abnormalities and have been recently identified as new KS genes [Bogershausen et \\ al., 2016]. Chromatin-modifying enzymes such as KMT2D play a fundamental role in \\ cell differentiation during embryonic development and mutations in these genes \\ manifest the same anatomical defects such as skeletal changes [Bogershausen et al., \\ 2015]. Mutations in $K M T 2 D$ are found in $55-80 \%$ of the patients with KS [Banka et \\ al., 2012], whereas deletions or mutations of $K D M 6 A$ are responsible for $9-14 \%$ of the \\ cases [Miyake et al., 2013b].
}


Skeletal abnormalities occur in about $80 \%$ of patients with KS. A patient with Kabuki syndrome and bilateral bipartite clavicles compatible with pseudoarthrosis was first described by Fryns and Devriendt [1998]. Hinrichs et al. [2002] described two more patients with KS, one with a right hypoplastic clavicle and the other with a bipartite right clavicle including a missing medial third. However, this specific feature has not been listed as a component manifestation of KS in OMIM, Orphanet or in Genereviews, and many clinicians are unaware of it. Here we report a fetus and a young boy who both have this rare feature associated with Kabuki syndrome and we review the literature for a similar clinical presentation in other chromo-domain remodeling disorders (ChRDs).

\section{Clinical reports}

\section{Patient 1:}

This was the second pregnancy of a Caucasian, non-consanguineous couple. A previous pregnancy resulted in a healthy boy. Antenatal scans showed left-sided cleft lip and palate, severe left hydronephrosis with oligohydramnios and normal fetal growth. There were concerns late in pregnancy about reduced fetal movements with the fetus maintaining position between scans with abnormal positioning of the hands and feet suspicious for arthrogryposis. On these grounds, the couple opted for termination. Consent was given for external examination and full autopsy, postmortem photographs, and genetic testing. Fetal growth parameters at 36 weeks of gestation were: weight $2.88 \mathrm{~kg}\left(50^{\text {th }}\right.$ centile, length $50 \mathrm{~cm}\left(97^{\text {th }}\right.$ centile $)$ and OFC $31.5 \mathrm{~cm}\left(25^{\text {th }}\right.$ centile $)$. We recognized a facial gestalt characterized by widely spaced eyes and long palpebral fissures (Figure 1). There was a left-sided cleft lip and palate and apparent brachycephaly. The chest appeared a little short with apparently high-set 
nipples. Limbs, abdomen, external genitalia, anus and back appeared normal. There were no contractures, talipes or limb deformities, although there were fetal pads.

Full autopsy revealed that the right clavicle was incomplete. There was a lateral piece of clavicle articulating with the acromion and a medial piece articulating with the sternum. Both fragments were well corticated, indicating that this was an interrupted/bipartite clavicle. Twelve ribs were present on the left side, in contrast to 11 on the right side.

\section{Patient 2:}

A fifteen-month-old boy was referred for a genetic evaluation to determine the cause of his poor weight gain and persistent gastro-esophageal reflux. He had been born at term with a birth weight of $3.25 \mathrm{~kg}\left(50^{\text {th }}\right.$ centile $)$. Following birth, he was noted to be hypoglycemic and became jaundiced within 24 hours. He required tube feeding for the first day and then established breast feeding. Weight gain was poor, and he required treatment with Omeprazole and Domperidone for reflux. He had surgery for inguinal hernia and orchidopexy for undescended testes at three months of age and had recurrent episodes of otitis media requiring antibiotics. A chest X-ray was carried out to investigate the possibility of aspiration and revealed some shadowing suggestive of infection in the right lung and a bipartite clavicle on the right side (Figure 2). He sat at ten months of age and said his first words at 15 months. He had good social skills, normal hearing and normal eyesight. On examination, his weight was $8.1 \mathrm{~kg}\left(0.4^{\text {th }}\right.$ centile $)$ and occipitofrontal circumference was $44.7 \mathrm{~cm}\left(0.4^{\text {th }}-2^{\text {nd }}\right.$ centile). He had apparently long palpebral fissures and joint laxity. Small fingertip pads were noted. An echocardiogram was normal. 


\section{Mutation analysis and Results}

In both patients, initial microarray analysis was performed on OGT ISCA 8x60K oligo array analysed with Cytosure Interpret v4.4.6 software against the GRCh37 Genome build. The average resolution of this array is $180 \mathrm{~kb}$ and showed normal results.

In view of the constellation of clinical features, Kabuki syndrome was suspected and $K M T 2 D$ mutation analysis was carried out. DNA was extracted from the spleen of patient 1 and from peripheral lymphocytes of patient 2. The coding sequence of KMT2D including splice donor and acceptor sites was amplified by long range PCR and sequenced on an Illumina MiSeq with a minimum of $100 \mathrm{x}$ coverage. Variant calling was carried out using an in-house custom bioinformatics pipeline. MLPA analysis was carried out to detect whole exon deletions or duplications.

In the first patient, the c.1452-5T $>\mathrm{G}$ variant in intron 44 of $K M T 2 D$ gene was identified. This variant has not been previously reported in Kabuki syndrome and it is not in the HGMD database. Splice site analysis using Alamut v.2.3.5 predicts that this variant may affect normal splicing of $K M T 2 D$ and may therefore be harmful. Parental testing showed normal results confirming that this was a de novo mutation in the fetus. In the second patient, the heterozygous variant c.6595delT in exon 31 of $K M T 2 D$ was found. This is a frameshift mutation which is predicted to be pathogenic and has been reported in a previous patient with Kabuki syndrome [Ng et al., 2010]. Parental testing showed that this was a de novo finding.

\section{Discussion}

Kabuki syndrome is a recognizable syndrome with characteristic facial features and various associated symptoms. The diagnosis is usually suspected on 
clinical grounds. Characteristic facial features along with congenital malformations (cardiac, renal, ano-rectal, skeletal) can lead to a clinical diagnosis that may be confirmed with genetic testing. However, given the evolving phenotype that becomes more obvious over time, a clinical diagnosis may be challenging in a fetus or newborn especially because the characteristic facial features become more evident during childhood [Dentici et al., 2014]. In this report, we describe an additional diagnostic clue for Kabuki syndrome that proved useful in arriving at a diagnosis in a fetus and a young child.

A bipartite clavicle has been described as a component manifestation of other genetic syndromes including chromosomal abnormalities such as chromosome 2q23.1 and 10p11-12 microdeletion syndromes which may be excluded by microarray analysis. Other syndromic conditions where bipartite/pseudofractured clavicles are part of a variable phenotype are Goltz syndrome (OMIM 305600) that can be distinguished because of the cutaneous abnormalities; van der Woude syndrome (IRF6-related disorder) (OMIM 119300) in which lip pits; ankyloblepharon or syndactyly usually occur; and the branchio-oto-renal syndrome (OMIM 113650) which is distinguished by the presence of branchial cysts and/or external ear anomalies. Short clavicles with a widened medullar cavity have been described in type IX Ehlers-Danlos syndrome [Sartoris et al., 1984]. Other differential diagnoses that may be excluded on X-ray are unilateral, congenital pseudoarthrosis of the clavicle (OMIM 118980); cleidocranial dysplasia (OMIM 119600) with hypoplastic or aplastic clavicles caused by $R U N X 2$ gene mutations; mandibuloacral dysplasia (OMIM 248370) that presents with hypoplastic clavicles, persistently wide sutures and multiple wormian bones; and limb/pelvis-hypoplasia/aplasia syndrome (OMIM 
276820) that is distinguished by severe malformations of upper and lower limbs with a severely hypoplastic pelvis.

Chromatin remodeling is an epigenetic mechanism that controls DNA accessibility to transcription. The group of disorders of chromatin remodeling is increasingly recognized and skeletal defects have been observed as part of the phenotypic spectrum of genetic syndromes caused by mutations in genes that interact in chromatin remodeling complexes. Floating-Harbor syndrome (FHS) (OMIM 136140) is one of these disorders and is characterized by typical craniofacial features, short stature, delayed osseous maturation, expressive-language deficits, and skeletal anomalies caused by mutations in the $S R C A P$. Pseudoarthrosis of the clavicle has been seen in several individuals with FHS [Hood et al., 2012]. Coffin-Siris syndrome (CSS) is characterized by development delay of varying degree, distinctive facial features, hypotonia, feeding difficulties and hypoplasia/aplasia of the fifth fingernails. One patient with CSS has been described with hypoplastic clavicles in the lateral portions of both sides [Schinzel, 1979]. Like KMT2D, SRCAP and the genes causing CSS are chromatin-remodeling factors. Although clavicular anomalies have not been reported in other conditions caused by chromatin remodeling genes, skeletal anomalies occur in many. For example, absent patellae occurs in the KAT6Bassociated disorders [Gannon, et al., 2014] and Weiss et al. [2016] recently described CHD4 mutations causing an intellectual disability syndrome with dysmorphism and skeletal anomalies, including vertebral fusions and tarsal coalition. CHD4 is a core component of the nucleosome remodeling complex.

In KS numerous de novo mutations have been described and mutations are distributed throughout the gene. The large majority of the mutations are nonsense or frameshift. Most identified mutations are truncating, likely leading to 
haploinsufficiency. Splice-site mutations are responsible for about $9 \%$ of pathologic allelic variants in KMT2D [Bogershausen and Wollnik, 2013]. The mutation found in the fetus has not been previously reported and is not found in human mutation databases, but it is likely to be pathogenic as it is predicted to affect a splice site. Some physical features are present more commonly in patients with KS and a KMT2D mutation compared to clinically diagnosed patients without a $K M T 2 D$ mutation [Makrythanasis et al., 2013], however correlations between mutation type and the phenotype have not yet been definitely established [Miyake et al., 2013a]. There are a few patients with bipartite clavicles described in the literature, but specific details of their mutations are not known. Both of our patients had mutations, albeit different ones, in the most common KS gene KMT2D. It will be interesting to see whether there is a correlation between a bipartite clavicle and mutations in KMT2D.

In conclusion, the spectrum of clinical features in Kabuki syndrome is wide and diagnosis can be difficult in very young patients. There have not been previous observations of Kabuki syndrome in a fetus with bipartite clavicle and therefore this report further expands the phenotypic spectrum and clinical variability of Kabuki syndrome. Moreover, this report proposes that bipartite clavicles may be, amongst other skeletal abnormalities, a diagnostic clue for syndromes caused by mutations in chromatin-remodeling genes.

\section{Conflict of interest}

The authors declare no conflict of interest.

\section{Acknowledgements}

We would like to thank the families for consenting to publication. 


\section{References}

Adam MP, Hudgins L, Hannibal M. 1993. Kabuki Syndrome. In: Pagon RA, Adam MP, Ardinger HH, Bird TD, Dolan CR, Fong CT, Smith RJH, Stephens K, editors. GeneReviews(R)Seattle (WA): University of Washington, Seattle.

Banka S, Veeramachaneni R, Reardon W, Howard E, Bunstone S, Ragge N, Parker MJ, Crow YJ, Kerr B, Kingston H, Metcalfe K, Chandler K, Magee A, Stewart F, McConnell VP, Donnelly DE, Berland S, Houge G, Morton JE, Oley C, Revencu N, Park SM, Davies SJ, Fry AE, Lynch SA, Gill H, Schweiger S, Lam WW, Tolmie J, Mohammed SN, Hobson E, Smith A, Blyth M, Bennett C, Vasudevan PC, GarciaMinaur S, Henderson A, Goodship J, Wright MJ, Fisher R, Gibbons R, Price SM, C de Silva D, Temple IK, Collins AL, Lachlan K, Elmslie F, McEntagart M, Castle B, Clayton-Smith J, Black GC, Donnai D. 2012. How genetically heterogeneous is Kabuki syndrome?: MLL2 testing in 116 patients, review and analyses of mutation and phenotypic spectrum. Eur J Hum Genet 20:381-388.

Bogershausen N, Gatinois V, Riehmer V, Kayserili H, Becker J, Thoenes M, SimsekKiper PO, Barat-Houari M, Elcioglu NH, Wieczorek D, Tinschert S, Sarrabay G, Strom TM, Fabre A, Baynam G, Sanchez E, Nurnberg G, Altunoglu U, Capri Y, Isidor B, Lacombe D, Corsini C, Cormier-Daire V, Sanlaville D, Giuliano F, Le Quan Sang KH, Kayirangwa H, Nurnberg P, Meitinger T, Boduroglu K, Zoll B, Lyonnet S, Tzschach A, Verloes A, Di Donato N, Touitou I, Netzer C, Li Y, Genevieve D, Yigit G, Wollnik B. 2016. Mutation Update for Kabuki Syndrome Genes KMT2D and KDM6A and Further Delineation of X-Linked Kabuki Syndrome Subtype 2. Hum Mutat 37(9):847-864.

Bogershausen N, Tsai IC, Pohl E, Kiper PO, Beleggia F, Percin EF, Keupp K, Matchan A, Milz E, Alanay Y, Kayserili H, Liu Y, Banka S, Kranz A, Zenker M, 
Wieczorek D, Elcioglu N, Prontera P, Lyonnet S, Meitinger T, Stewart AF, Donnai D, Strom TM, Boduroglu K, Yigit G, Li Y, Katsanis N, Wollnik B. 2015. RAP1mediated MEK/ERK pathway defects in Kabuki syndrome. J Clin Invest 125:35853599.

Bogershausen N, Wollnik B. 2013. Unmasking Kabuki syndrome. Clin Genet 83:201211.

Coffin GS, Siris E. 1985. The Coffin-Siris syndrome. Am.J.Dis.Child. 139:12.

Dentici ML, Di Pede A, Lepri FR, Gnazzo M, Lombardi MH, Auriti C, Petrocchi S, Pisaneschi E, Bellacchio E, Capolino R, Braguglia A, Angioni A, Dotta A, Digilio MC, Dallapiccola B. 2014. Kabuki syndrome: clinical and molecular diagnosis in the first year of life. Arch Dis Child 100(2):158-164.

Fryns JP, Devriendt K. 1998. Hypoplastic claviculae in the Kabuki (Niikawa-Kuroki) syndrome. Genet Couns 9:57-58.

Gannon T, Perveen R, Schlecht H, Ramsden S, Anderson B, Kerr B, Day R, Banka S, Suri M, Berland S, Gabbett M, Ma A, Lyonnet S, Cormier-Daire V, Yilmaz R, Borck G, Wieczorek D, Anderlid BM, Smithson S, Vogt J, Moore-Barton H, Simsek-Kiper PO, Maystadt I, Destree A, Bucher J, Angle B, Mohammed S, Wakeling E, Price S, Singer A, Sznajer Y, Toutain A, Haye D, Newbury-Ecob R, Fradin M, McGaughran J, Tuysuz B, Tein M, Bouman K, Dabir T, Van den Ende J, Luk HM, Pilz DT, Eason J, Davies S, Reardon W, Garavelli L, Zuffardi O, Devriendt K, Armstrong R, Johnson D, Doco-Fenzy M, Bijlsma E, Unger S, Veenstra-Knol HE, Kohlhase J, Lo IF, DDD study, Smith J, Clayton-Smith J. 2014. Further delineation of the KAT6B molecular and phenotypic spectrum. Eur J Hum Genet Sep; 23(9):1165-1170.

John Wiley \& Sons, Inc. 
Goo YH, Sohn YC, Kim DH, Kim SW, Kang MJ, Jung DJ, Kwak E, Barlev NA, Berger SL, Chow VT, Roeder RG, Azorsa DO, Meltzer PS, Suh PG, Song EJ, Lee KJ, Lee YC, Lee JW. 2003. Activating signal cointegrator 2 belongs to a novel steady-state complex that contains a subset of trithorax group proteins. Mol Cell Biol 23:140-149.

Hinrichs B, Gramss B, Meinecke P. 2002. Defective clavicles in Kabuki syndrome. Genet Couns 13:477-479.

Hood RL, Lines MA, Nikkel SM, Schwartzentruber J, Beaulieu C, Nowaczyk MJ, Allanson J, Kim CA, Wieczorek D, Moilanen JS, Lacombe D, Gillessen-Kaesbach G, Whiteford ML, Quaio CR, Gomy I, Bertola DR, Albrecht B, Platzer K, McGillivray G, Zou R, McLeod DR, Chudley AE, Chodirker BN, Marcadier J, FORGE Canada Consortium, Majewski J, Bulman DE, White SM, Boycott KM. 2012. Mutations in SRCAP, encoding SNF2-related CREBBP activator protein, cause Floating-Harbor syndrome. Am J Hum Genet 90:308-313.

Kuroki Y, Suzuki Y, Chyo H, Hata A, Matsui I. 1981. A new malformation syndrome of long palpebral fissures, large ears, depressed nasal tip, and skeletal anomalies associated with postnatal dwarfism and mental retardation. J.Pediatr. 99:570-573.

Lederer D, Grisart B, Digilio MC, Benoit V, Crespin M, Ghariani SC, Maystadt I, Dallapiccola B, Verellen-Dumoulin C. 2012. Deletion of KDM6A, a histone demethylase interacting with MLL2, in three patients with Kabuki syndrome. Am J Hum Genet 90:119-124.

Li Y, Bogershausen N, Alanay Y, Simsek Kiper PO, Plume N, Keupp K, Pohl E, Pawlik B, Rachwalski M, Milz E, Thoenes M, Albrecht B, Prott EC, Lehmkuhler M, Demuth S, Utine GE, Boduroglu K, Frankenbusch K, Borck G, Gillessen-Kaesbach 
G, Yigit G, Wieczorek D, Wollnik B. 2011. A mutation screen in patients with

Kabuki syndrome. Hum Genet 130:715-724.

Makrythanasis P, van Bon BW, Steehouwer M, Rodriguez-Santiago B, Simpson M, Dias P, Anderlid BM, Arts P, Bhat M, Augello B, Biamino E, Bongers EM, Del

Campo M, Cordeiro I, Cueto-Gonzalez AM, Cusco I, Deshpande C, Frysira E, Izatt L,

Flores R, Galan E, Gener B, Gilissen C, Granneman SM, Hoyer J, Yntema HG, Kets

CM, Koolen DA, Marcelis C, Medeira A, Micale L, Mohammed S, de Munnik SA,

Nordgren A, Psoni S, Reardon W, Revencu N, Roscioli T, Ruiterkamp-Versteeg M,

Santos HG, Schoumans J, Schuurs-Hoeijmakers JH, Silengo MC, Toledo L, Vendrell

T, van der Burgt I, van Lier B, Zweier C, Reymond A, Trembath RC, Perez-Jurado L,

Dupont J, de Vries BB, Brunner HG, Veltman JA, Merla G, Antonarakis SE,

Hoischen A. 2013. MLL2 mutation detection in 86 patients with Kabuki syndrome: a genotype-phenotype study. Clin Genet 84:539-545.

Micale L, Augello B, Fusco C, Selicorni A, Loviglio MN, Silengo MC, Reymond A,

Gumiero B, Zucchetti F, D'Addetta EV, Belligni E, Calcagni A, Digilio MC,

Dallapiccola B, Faravelli F, Forzano F, Accadia M, Bonfante A, Clementi M, Daolio

C, Douzgou S, Ferrari P, Fischetto R, Garavelli L, Lapi E, Mattina T, Melis D,

Patricelli MG, Priolo M, Prontera P, Renieri A, Mencarelli MA, Scarano G, della

Monica M, Toschi B, Turolla L, Vancini A, Zatterale A, Gabrielli O, Zelante L, Merla

G. 2011. Mutation spectrum of MLL2 in a cohort of Kabuki syndrome patients.

Orphanet J Rare Dis 6:38. doi: 10.1186/1750-1172-6-38

Miyake N, Koshimizu E, Okamoto N, Mizuno S, Ogata T, Nagai T, Kosho T, Ohashi

H, Kato M, Sasaki G, Mabe H, Watanabe Y, Yoshino M, Matsuishi T, Takanashi J, Shotelersuk V, Tekin M, Ochi N, Kubota M, Ito N, Ihara K, Hara T, Tonoki H, Ohta

T, Saito K, Matsuo M, Urano M, Enokizono T, Sato A, Tanaka H, Ogawa A, Fujita T, 
Hiraki Y, Kitanaka S, Matsubara Y, Makita T, Taguri M, Nakashima M, Tsurusaki Y, Saitsu H, Yoshiura K, Matsumoto N, Niikawa N. 2013a. MLL2 and KDM6A mutations in patients with Kabuki syndrome. Am J Med Genet A 161A:2234-2243.

Miyake N, Mizuno S, Okamoto N, Ohashi H, Shiina M, Ogata K, Tsurusaki Y, Nakashima M, Saitsu H, Niikawa N, Matsumoto N. 2013b. KDM6A point mutations cause Kabuki syndrome. Hum Mutat 34:108-110.

Ng SB, Bigham AW, Buckingham KJ, Hannibal MC, McMillin MJ, Gildersleeve HI, Beck AE, Tabor HK, Cooper GM, Mefford HC, Lee C, Turner EH, Smith JD, Rieder MJ, Yoshiura K, Matsumoto N, Ohta T, Niikawa N, Nickerson DA, Bamshad MJ, Shendure J. 2010. Exome sequencing identifies MLL2 mutations as a cause of Kabuki syndrome. Nat Genet 42:790-793.

Niikawa N, Kuroki Y, Kajii T, Matsuura N, Ishikiriyama S, Tonoki H, Ishikawa N, Yamada Y, Fujita M, Umemoto H. 1988. Kabuki make-up (Niikawa-Kuroki) syndrome: a study of 62 patients. Am J Med Genet 31:565-589.

Niikawa N, Matsuura N, Fukushima Y, Ohsawa T, Kajii T. 1981. Kabuki make-up syndrome: a syndrome of mental retardation, unusual facies, large and protruding ears, and postnatal growth deficiency. J Pediatr 99:565-569.

Paulussen AD, Stegmann AP, Blok MJ, Tserpelis D, Posma-Velter C, Detisch Y, Smeets EE, Wagemans A, Schrander JJ, van den Boogaard MJ, van der Smagt J, van Haeringen A, Stolte-Dijkstra I, Kerstjens-Frederikse WS, Mancini GM, Wessels MW, Hennekam RC, Vreeburg M, Geraedts J, de Ravel T, Fryns JP, Smeets HJ, Devriendt K, Schrander-Stumpel CT. 2011. MLL2 mutation spectrum in 45 patients with Kabuki syndrome. Hum Mutat 32(2):E2018-2025. 
Sartoris DJ, Luzzatti L, Weaver DD, Macfarlane JD, Hollister DW, Parker BR. 1984.

Type IX Ehlers-Danlos syndrome. A new variant with pathognomonic radiographic features. Radiology 152:665-670.

Schinzel A. 1979. The Coffin-Siris syndrome. Acta Paediatr.Scand. 68:449-452.

Weiss K, Terhal PA, Cohen L, Bruccoleri M, Irving M, Martinez AF, Rosenfeld JA, Machol K, Yang Y, Liu P, Walkiewicz M, Beuten J, Gomez-Ospina N, Haude K, Fong CT, Enns GM, Bernstein JA, Fan J, Gotway G, Ghorbani M, DDD Study, van

Gassen K, Monroe GR, van Haaften G, Basel-Vanagaite L, Yang XJ, Campeau PM, Muenke M. 2016. De Novo Mutations in CHD4, an ATP-Dependent Chromatin Remodeler Gene, Cause an Intellectual Disability Syndrome with Distinctive Dysmorphisms. Am J Hum Genet 99:934-941. 


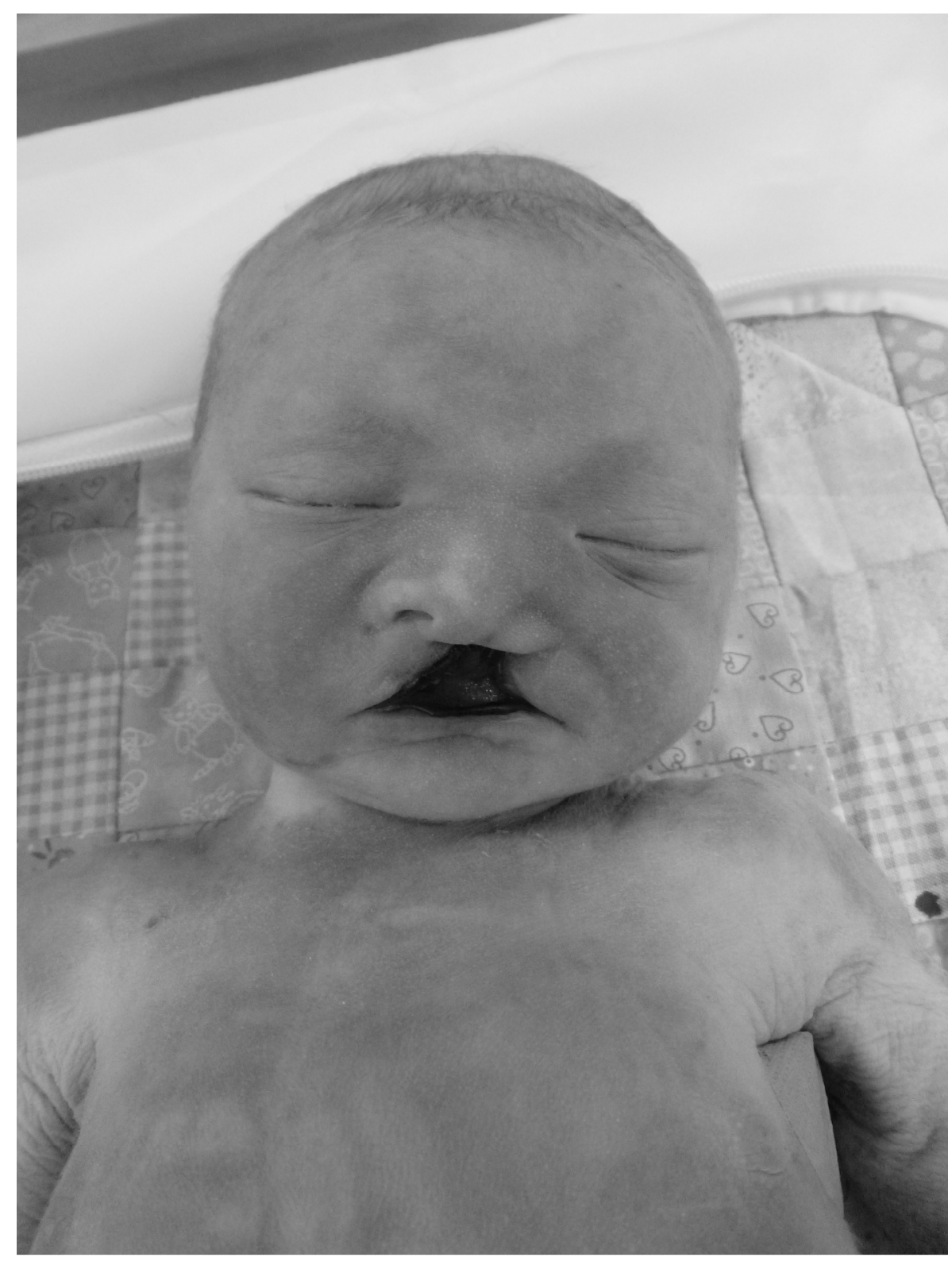

Figure 1. Facial features of the fetus. $457 \times 609 \mathrm{~mm}(180 \times 180 \mathrm{DPI})$

John Wiley \& Sons, Inc. 


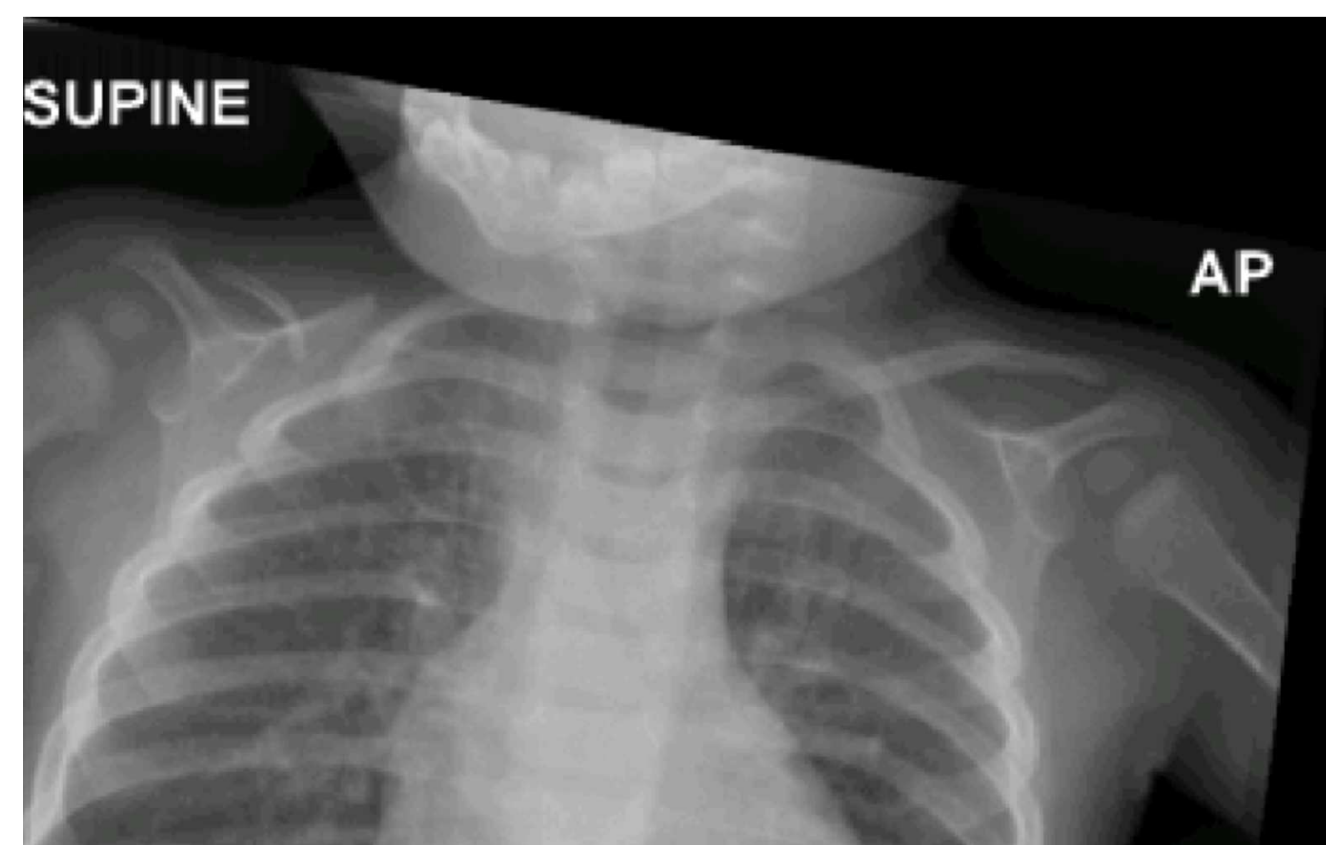

Figure 2. Chest X-ray shows a bipartite clavicle on the right side. $244 \times 155 \mathrm{~mm}(300 \times 300 \mathrm{DPI})$ 